\title{
Seasonal Differences in the Element Con- tent of Wyoming Big Sagebrush
}

\author{
LARRY P. GOUGH AND JAMES A. ERDMAN
}

\begin{abstract}
Concentrations of 30 elements in samples from a stand of $\boldsymbol{A}$ rtemisia tridentata subsp. wyomingensis Beetle \& Young were determined for young and old tissue in September, January, April, and July, 1975-76. Elements with similar seasonal trends were grouped. Changes in the Concentration of the major essential elements $(\mathrm{Ca}$, $\mathrm{Mg}, \mathrm{P}, \mathrm{K}$, and $\mathrm{S}$ ) with season directly reflect phenological events which alter the proportion of leaf-to-stem tissue in the samples. In general, the element composition of younger tissue fluctuates more, has higher concentrations, and shows greater differences between seasons than older material. These data stress the influence of season, on the element concentrations in plant tissue and underscore the need for caution when comparing sample data with established element concentration baselines.
\end{abstract}

Baseline concentrations for both biologically "active" and "inactive" elements in native plants of the northern Great Plains are of considerable importance. With an increase in the surface mining of minerals, and subsequent land reclamation, alterations can be expected in the element content of plants revegetating these areas. Such changes can be better interpreted, however, if the magnitude of local seasonal concentration differences, intrinsic to the plant, is known. As a first approximation of the seasonal changes for Wyoming big sagebrush, we present the concentration of 30 elements in the dry material of plants collected from a small locality in the eastern plains of Wyoming.

Only a few studies of the element content of big sagebrush in the western United States have been made (Nat. Res. Council and Dep. Agr. 1969; Harner and Harper 1973; Wallace et al. 1973; Mack 1977). These reports, in general, are concerned with the forage quality of big sagebrush and therefore give concentrations for only a few of the major elements. Connor et al. (1976) reported expected baseline

\footnotetext{
Authors are botanists, U.S. Geological Survey, Box 25046, Denver Federal Center, Denver, Colorado 80225 .

We gratefully acknowledge the analytical services of B.L. Bolton, N.M. Conklin. T.F. Harms, and C.S.E. Papp; the field assistance of B.M. Anderson and R.C. Severson; and the taxonomic verification by A.H. Winward.

Manuscript received March 23, 1979

concentrations for 14 elements (both major and trace) in big sagebrush for the Powder River Basin of Wyoming and Montana. Hamilton (1958) presented some seasonal element composition data (April through November) for a variety of Wyoming shrubs including $A$. tridentata. The Russian literature appears to be quite extensive in the field of sagebrush biogeochemistry (Rodin et al. 1972; Miroshnichenko 1976), but of course these studies give data for European and Asian species of Artemisia, not for $A$. tridentata.

The taxonomy of the section Tridentatae of the genus Artemisia (Beetle 1960) has been under considerable study recently (see, for example, West et al. 1978), and appears to be far from settled. In conformity with the current literature, we recognize the importance of subspecies in this complex group and have confined our study to a population of $A$. tridentata subsp. wyomingensis (Beetle and Young 1965). By avoiding a mixture of subspecies in the study design, possible subspecific differences in phenology and physiology and therefore, presumably, differences in element uptake were eliminated.

\section{Study Area and Methods}

The study area was located about $4.5 \mathrm{~km}$ west of Glendo (Platte County), Wyoming, $\left(42^{\circ} 31^{\prime} \mathrm{N}, 105^{\circ} 4^{\prime} \mathrm{W}\right)$. According to Dunnewald (1957) the soils of this region are broadly classified as brown sandy loams underlain by rocks of Tertiary age. The study area of about 5 ha has a slight slope toward the northeast and is at an elevation of about $1,500 \mathrm{~m}$. There was a great deal of snow accumulation when the winter collections were made because of the slope and the prevailing westerly winds. The vegetation was dominated by Wyoming big sagebrush and blue grama (Bouteloua gracilis) with scattered silver and black sagebrush ( $A$. cana and $A$. nova, respectively).

Within the study area ten sites were selected and marked. Each site consisted of numerous shrubs from which the samples were taken. On September 12, 1975, January 14, 1976, April 14, 1976, 
and July 14, 1976, the area was visited and samples were collected. At each site composite samples were collected from a random selection of approximately 4 to 8 shrubs. These samples consisted of young stems, leaves, and inflorescences (material that was $<2$ years old, or roughly, the terminal 10 to $20 \mathrm{~cm}$ of the branches) and old stems (material that was $>3$ years old). The $<2$-year-old collections were considered a composite sample of browse material. The proportion of leaf:stem:inflorescence varied with the season for the "young" material whereas the "old" material consisted mostly of woody stems. Voucher specimens are stored in the herbarium of the U.S. Geological Survey in Denver.

In the laboratory, the 80 samples ( 2 samples $\times 10$ sites $\times 4$ seasons) were dried at $38^{\circ}-40^{\circ} \mathrm{C}$ for 48 hours and then ground in a Wiley mill to pass a $1.3-\mathrm{mm}$ screen. The samples were not washed. Twenty samples, selected at random, were split and the analytical sequence of the entire suite of 100 samples was randomized. The analysis of blind splits provided a measure of laboratory precision, whercas the analysis of the samples in a randomized sequence insured that possible analytical bias would be converted to random error (Miesch 1976). The homogenized ground material was either ashed by dry ignition at $500^{\circ} \mathrm{C}$ for $24 \mathrm{hr}$ or by wet digestion (Harms 1976). All element analyses were performed in the Denver Labora-

Table 1. Analytical methods and the proportion of total error variance explained as analytical for 30 elements and ash yield in young and old tissue of Artemisia tridentata ssp. wyomingensis.

\begin{tabular}{|c|c|c|c|}
\hline Element, or ash & $\begin{array}{l}\text { Analytical } \\
\text { method }^{\mathrm{a}} \text { । }\end{array}$ & $\begin{array}{l}\text { Percent of total } \\
\text { error variance ex- } \\
\text { plained as } \\
\text { analytical }^{\text {b }}\end{array}$ & $\begin{array}{l}\text { AoV on differ- } \\
\text { ences between } \\
\text { element content } \\
\text { of young and old } \\
\text { tissue }^{c}\end{array}$ \\
\hline Ash & - & 8.5 & $* *$ \\
\hline Aluminum & SQS & 21 & $* *$ \\
\hline Antimony & $\mathrm{AA}$ & 7.6 & \\
\hline Arsenic & $\mathrm{AA}$ & 6.4 & \\
\hline Barium & SQS & 34 & $* *$ \\
\hline Boron & SQS & 61 & $* *$ \\
\hline Cadmium & $\mathrm{AA}$ & 8.0 & $* *$ \\
\hline Calcium & AA & 28 & ** \\
\hline Chromium & SQS & 29 & $* *$ \\
\hline Cobalt & $\mathrm{AA}$ & 30 & \\
\hline Copper & AA & 7.6 & $* *$ \\
\hline Fluorine & SIE & 72 & \\
\hline Iron & SQS & 24 & $* *$ \\
\hline Lead & SQS & 47 & $* *$ \\
\hline Lithium & AA & 43 & $*$ \\
\hline Magnesium & AA & 6.6 & $* *$ \\
\hline Manganese & SQS & 42 & ** \\
\hline Mercury & FL-AA & 17 & \\
\hline Molybdenum & COLR & 13 & ** \\
\hline Nickel & SQS & 23 & $* *$ \\
\hline Phosphorus & COLR & 2.5 & $* *$ \\
\hline Potassium & AA & 3.6 & $* *$ \\
\hline Selenium & FLUR & 5.3 & $* *$ \\
\hline Sodium & AA & 12 & $* *$ \\
\hline Strontium & SQS & 41 & $*$ \\
\hline Sulfur (total) & TURB & 5.2 & ** \\
\hline Titanium & SQS & 37 & $* *$ \\
\hline Uranium & FLUR & 7.7 & \\
\hline Vanadium & SQS & 20 & $*$ \\
\hline Zinc & $\mathrm{AA}$ & 4.7 & $* *$ \\
\hline Zirconium & SQS & 52 & ** \\
\hline
\end{tabular}

${ }^{a}$ SQS, semiquantitative spectrography; AA, atomic absorption spectroscopy; SIE, selective ion electrode; FL-AA, flameless atomic absorption spectroscopy; COLR, colorimetric; FLUR, fluorometric; TURB, turbidimetric.

${ }^{\mathrm{b}}$ Results of a one-way two-level analysis-of-variance which compared the element content of 20 sample splits.

${ }^{c_{* *}}$ and *, F-ratio significance at the 0.01 and 0.05 probability levels respectively; blanks mean non-significance.
Table 2. Elements in the ash of Artemisia tridenta ssp. wyomingensis samples which had concentrations below the lower limit of determination (LLD).

\begin{tabular}{|c|c|c|c|c|c|c|}
\hline \multirow{3}{*}{ Element } & \multicolumn{2}{|c|}{ Approximate } & \multirow{2}{*}{\multicolumn{2}{|c|}{ Detection }} & \multirow{2}{*}{ ratio $^{c}$ by } & \multirow[b]{2}{*}{ season } \\
\hline & LLD & Sample & & ion rati & & \\
\hline & & & Spring & Suminer & & \\
\hline \multirow[t]{2}{*}{ Antimony } & 0.05 & $Y$ & $10: 10$ & $10: 10$ & $4: 10$ & $10: 10$ \\
\hline & & $\mathrm{O}$ & $10: 10$ & $10: 10$ & $8: 10$ & $10: 10$ \\
\hline \multirow[t]{2}{*}{ Cobalt } & 1 & $\mathrm{Y}$ & $9: 10$ & $7: 10$ & $8: 10$ & $9: 10$ \\
\hline & & $\mathrm{O}$ & $10: 10$ & $10: 10$ & $8: 10$ & $9: 10$ \\
\hline \multirow[t]{2}{*}{ Lead } & 10 & $\mathrm{Y}$ & $10: 10$ & $7: 10$ & $9: 10$ & $10: 10$ \\
\hline & & $\mathrm{O}$ & $10: 10$ & $10: 10$ & $10: 10$ & $10: 10$ \\
\hline \multirow[t]{2}{*}{ Lithium } & 4 & $\mathrm{Y}$ & $10: 10$ & $9: 10$ & $10: 10$ & $10: 10$ \\
\hline & & $\mathrm{O}$ & $10: 10$ & $10: 10$ & $10: 10$ & $10: 10$ \\
\hline \multirow[t]{2}{*}{ Uranium } & .4 & $\mathrm{Y}$ & $10: 10$ & $4: 10$ & 10:10 & $10: 10$ \\
\hline & & $\mathrm{O}$ & $10: 10$ & $9: 10$ & 10:10 & $10: 10$ \\
\hline \multirow[t]{2}{*}{ Zirconium } & 10 & $\mathrm{Y}$ & $10: 10$ & $0: 10$ & $9: 10$ & $10: 10$ \\
\hline & & $\mathrm{O}$ & $10: 10$ & $9: 10$ & $9: 10$ & $10: 10$ \\
\hline
\end{tabular}

${ }^{\text {a }}$ Parts per million in ash, except antimony which is determined on dry material.

${ }^{b} \mathrm{Y}$, predominantly young leaves and stems $(<2$ years); $O$, predominantly old stems $(>$ 3 years).

${ }^{c}$ Number of values above the lower limit of determination to the number of samples analyzed.

tories of the U.S. Geological Survey by the methods listed in Table 1.

\section{Statistical Design and Data Analysis}

Mayland and Murray (1979) recommended that data on the element composition of sagebrush, in order to be most useful, should always be expressed on a dry matter basis. Therefore, except for those volatile elements ( $\mathrm{Sb}, \mathrm{As}, \mathrm{F}, \mathrm{Hg}$, Se, and $\mathrm{S}$ ) determined on dry material, element concentrations reported in ash were converted to concentrations in dry material. All of the dry-weight concentration data were converted to logarithms because the frequency distributions of the log data were found to be more symmetrical. Subsequent statistical tests were, therefore, run on the log-transformed data.

In several instances, concentrations for some elements were reported by the analyst to be below the lower limit of determination (LLD) or not detected at all. These censored values were replaced in the data matrix with an arbitrary concentration equal to 0.7 times the LLD in ash. The 6 elements with censoring are listed in Table 2. Except for $\mathrm{Zr}$ concentrations in young tissue, no more than $25 \%$ of the data for a specific element were censored. Other procedures were tested for the replacement of the censored. values both before and after dry weight conversions were made. For this particular data set, no important differences in the results of the Duncan multiple range test (Duncan 1955) or of the analysis

Table 3. Two-way analysis-of-variance design.

\begin{tabular}{lccccc}
\hline \hline Source of variation & & $\begin{array}{c}\text { Degrees of } \\
\text { freedom }\end{array}$ & $\begin{array}{c}\text { Estimated mean } \\
\text { square }\end{array}$ & F-test \\
\hline Between sample types & $\alpha_{\mathrm{i}}$ & 1 & $\mathrm{M}_{1}=\mathrm{S}_{\boldsymbol{\epsilon}}^{2}+10_{\alpha \beta}^{2}+40 \mathrm{~S}_{\alpha}^{2}$ & $\mathrm{M}_{1} / \mathrm{M}_{4}$ \\
Between seasons & $\beta_{\mathrm{j}}$ & 3 & $\mathrm{M}_{2}=\mathrm{S}_{\boldsymbol{\epsilon}}^{2}+10_{\alpha \beta}^{2}+20 \mathrm{~S}_{\beta}^{2}$ & $\mathrm{M}_{2} / \mathrm{M}_{4}$ \\
Interaction & $\alpha \beta_{\mathrm{ij}}$ & 3 & $\mathrm{M}_{3}=\mathrm{S}_{\epsilon}^{2}+10_{\alpha \beta}^{2}$ & $\mathrm{M}_{3} / \mathrm{M}_{4}$ \\
Error & $\epsilon_{(\mathrm{ijk})}$ & 72 & $\mathrm{M}_{4}=\mathrm{S}_{\boldsymbol{\epsilon}}^{2}$ & \\
Total & & 79 & & \\
\hline
\end{tabular}

${ }^{\mathrm{a}}$ Between predominantly young leaves and stems $(<2$ years) and old stems $(>3$ years). 
of variance were obtained using these various methods of data management. The statistical design used for partitioning the variance between tissue types and between seasons is given in Table 3 .

\section{Results}

\section{Phenological and Ash Yield Considerations}

Seasonal patterns in the element content of big sagebrush cannot be properly evaluated without a knowledge of sagebrush ecophysiology and phenology. Several important studies have appeared dealing with the seasonal photosynthetic rates (DePuit and Caldwell 1973) and mineral cycling (Mack 1977) of basin big sagebrush, and seasonal root growth of Wyoming big sagebrush (Fernandez and Caldwell 1975). Basic to these studies of seasonal changes is the statement by DePuit and Caldwell (1973 p. 433) that physiological activity (specifically, photosynthesis) varies “...both as a response to changing environmental conditions and as a reflection of phenological changes in the plant itsclf."

Although the specific timing of phenological events varies, a general life-history for sagebrush is useful. An abbreviated phenological sequence for basin big sagebrush from northern Utah (DePuit and Caldwell 1973) follows:

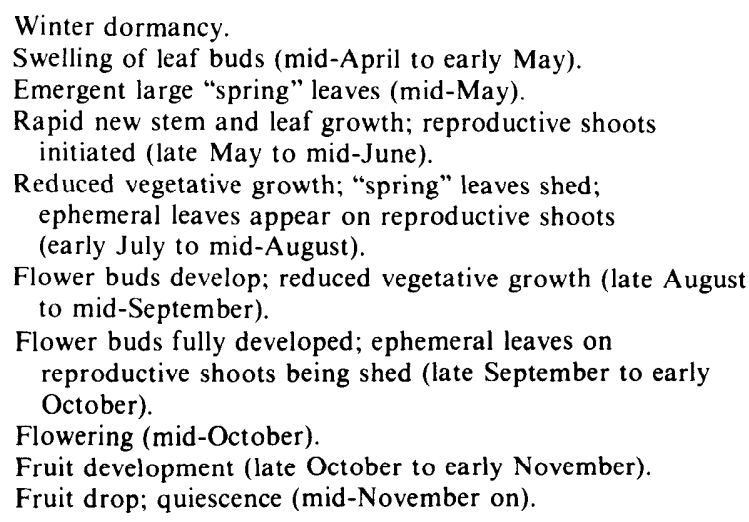

We have assumed that the phenological stages of Wyoming big sagebrush are similar to those given above. The ash yield data (Fig. 1) tend to support this assumption. In a separate (unpublished) study, the average ash yield for various tissue types of 3 samples of Wyoming big sagebrush collected in July were as follows: leaves, $6.3 \%$; young vegetative stems, $3.6 \%$; mature stems, $2.6 \%$. The 4 seasonal means for young tissue are significantly different from each other (Fig. 1). Judged by the phenological sequence given above, the relative proportion of leaf:stem:inflorescence material can be expected to vary with the season. The lowest ash yield $(4.0 \%)$ was found in mid-April. This time immediately precedes accelerated vegetative growth and follows the leaf and inflorescence shedding of winter. The samples, therefore, were composed predominantly of low-ash-yielding stem material. Vegetative leaf and stem growth is around its maximum in mid-July, which was the period of highest ash yield $(5.4 \%)$. As fall and winter approach, the general phenological scheme is toward a decrease in the production of high-ash-yielding leaf material because of the continued shedding of ephemeral leaves; however, the effect of this trend is probably ameliorated by accelerated growth and development of reproductive stems.

If the fluctuation in ash yield is intrinsic in nature, then soil contamination (consisting of silica-rich sands, silts, and clays) would be of little importance. Plants, in general, tend to concentrate most elements relative to soil concentrations. Concerning soil elements Shacklette (1965 p. 16) stated: "Contamination of the plant sample with soil would decrease these element percentages in the ash; thus the values reported for these elements err only by being too low, insofar as soil contamination as a source of error is concerned." He continues by stating that elements such as Al, $\mathrm{Si}, \mathrm{Ti}$, and $\mathrm{Zr}$ are found in greater concentrations in soil than in plants and would therefore be useful in determining the degree to which ash yield is affected by soil.

We think that the ash yield trends observed in this study are predominantly intrinsic, and, in all probability, any error introduced by soil contamination is overwhelmed by the natural variability in ash yield. This is true for several reasons. (1) Concentrations of $\mathrm{Al}, \mathrm{Ti}$, and $\mathrm{Zr}$ (Si was not analyzed) are very small compared with the concentrations of the major essential elements $\mathrm{K}, \mathrm{Ca}, \mathrm{Mg}, \mathrm{P}$, and $\mathrm{S}$. (2) Samples of young tissue show strong inverse relations between ash yield and the soil "resistate" elements $\mathrm{Al}, \mathrm{Ti}$, and $\mathrm{Zr}$, whereas strong direct relations exist between ash yield and the major essential elements (Fig. 1). These relations imply that the proportion of the soil resistate elements to the major elements in young tissue remains fairly constant with season and that the former group is being "diluted"by the latter. (3) Experience with numerous data sets of different plant materials has shown us that samples with known varying degrees of soil contamination show wide fluctuations in ash yield values and therefore large geometric deviations. Because the Duncan's test (Fig. 1) was able to separate as being distinctive the four seasonal means for young tissue, even though the range of means was only 4.0-5.4\% (Fig. 1), the effect of small geometric deviation is apparent.

\section{Seasonal Patterns}

Figure 1 presents the geometric means of 30 elements and ash yield for the 2 tissue types at 4 seasons of the year. The lines connecting the means are presented only as an aid in the classification of groups of elements and do not imply an extrapolation of the data between points. Upper-case superscripts were used to group the young tissue means; lowercase superscripts group the means for old tissue.

In general, our results for the major elements compare well with those concentrations given in the literature. Possible exceptions include (1) Ca-our values are nearly 3-times lower than those reported by Wallace et al. (1973) and Mack (1977), and (2) $\mathrm{Na}$-our values are an order of magnitude below those of Wallace et al. (1973). The concentration of 14 elements in our samples was also compared with the calculated expected $95 \%$ range (baseline) for those same elements in sagebrush samples (probably susbsp. wyomingensis) collected throughout the Powder River Basin (Connor et al. 1976). With the exception of our B and $\mathrm{Sr}$ values (which were high), nearly all of our values fell within the anticipated range.

Figure 1 is divided into four groups, each of which is composed of elements with similar seasonal patterns.

\section{Group I}

The trends in the young tissue for this group of elements ( $\mathrm{Ca}, \mathrm{Cu}, \mathrm{Mg}, \mathrm{Ni}, \mathrm{P}, \mathrm{K}, \mathrm{S}$, and $\mathrm{Zn}$ ) are dominated by (1) strong positive relations among themselves and with ash yield; (2) high values in July or July and September; and (3) the major essential elements (with the exception of $\mathrm{Cu}$ and $\mathrm{Zn}$, which are trace essentials, and $\mathrm{Ni}$ ). We believe that these 

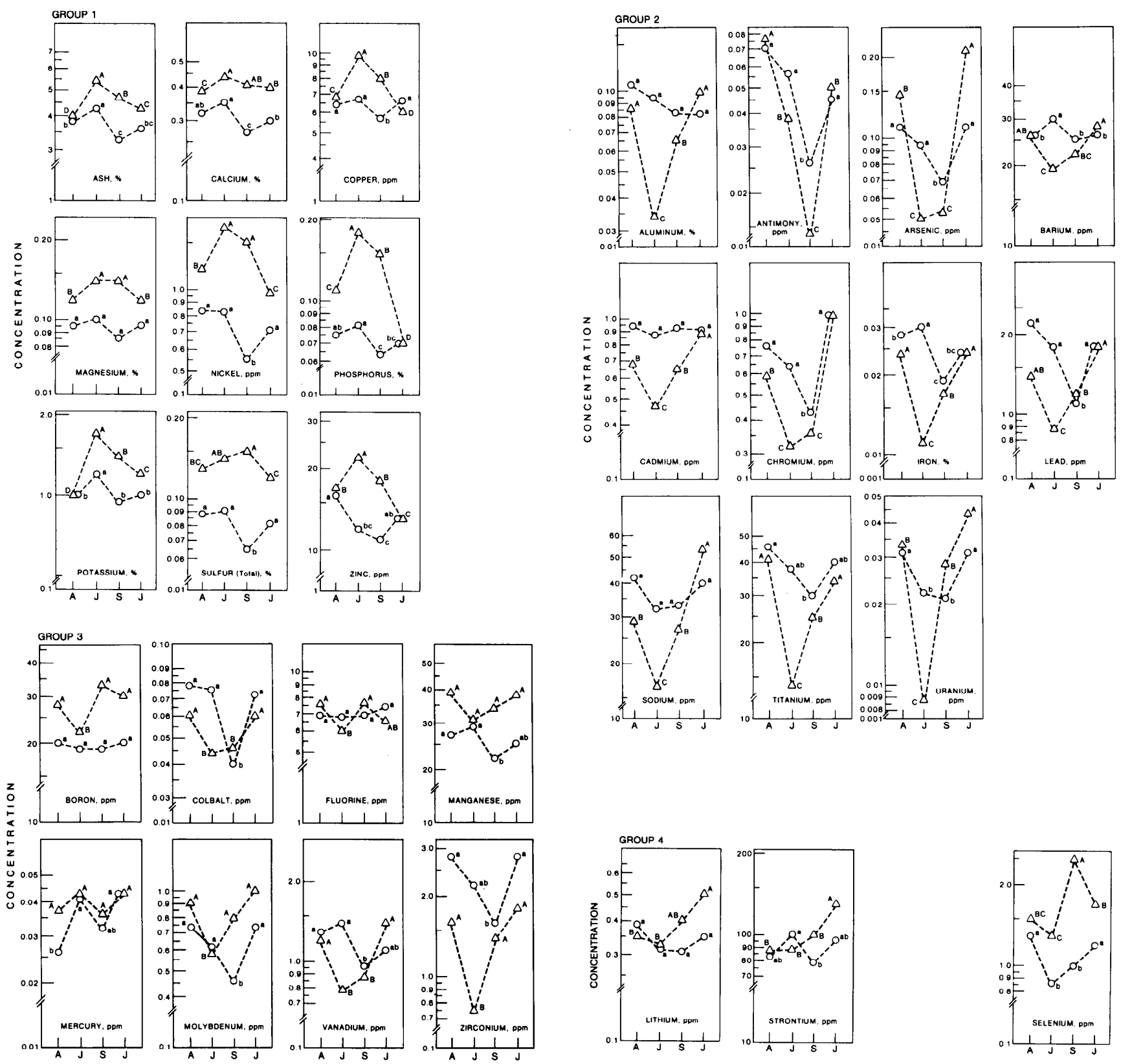

Fig. 1. Seasonal changes in the element composition of Wyoming big sagebrush dry material grouped according to similar overall trends (see text for discussion). The triangles show seasonal geometric means for young tissue (predominantly<2.year-old stems, leaves, and inflorescences) and the circles show means for old tissue (predominantly >3-year-old stems). Results of Duncan's test are reported for the seasonal means of each tissue type using upper- (young tissue) and lower-case (old tissue) superscripts. Element concentration is denoted in either percent or parts per million (ppm) along the $Y$-axis whereas $A, J, S$, and J, along the X-axis, denote the sampling dates of April, July, September, and January respectively.

trends reflect both early season rapid vegetative growth and uptake of ash-forming elements (Hamilton 1958) and the greater proportion of leaf-to-stem material in the early summer period.

A different trend for these elements is shown for the old stems. Again, high values tend to appear in July (and low values in September), but the seasonal means are less distinguishable. Differences in the seasonal means for $\mathrm{Mg}$ are not significant and differences among the means for $\mathrm{Cu}, \mathrm{Ni}, \mathrm{K}$, and $\mathrm{S}$, although real, are generally less than those observed in young tissue. The concentrations of the elements in this group were significantly less in old tissue (Table 1) than in young. These results are similar to those of Miroshnichenko (1976), who found that the concentrations of $\mathrm{Ca}, \mathrm{Mg}, \mathrm{P}, \mathrm{K}$, and $\mathrm{S}$ were higher in the young vegetative tissue than in older tissue of $A$. pauciflora from Kazakhstan.

A comparison of the September-to-January Group 1 values shows a trend downward for young tissue and upward for old tissue. This may reflect a return of these elements from the leaves to the stems. Similar late-season trends for $\mathrm{Ca}, \mathrm{K}, \mathrm{Mg}, \mathrm{N}$, and $\mathrm{P}$ in 5 species of shrubs in Minnesota were recently interpreted as possibly reflecting return-flow (Grigal et al. 1976).

\section{Group 2}

The seasonal trends for the concentration of the elements in the young tissue of this group are the inverse of those observed in Group 1, in that low values occurred in July or September, or July and September. Some of the highest 
values often occurred in January or April. At these sampling times the proportion of high-ash-yielding leaf tissue is low compared with low-ash-yielding stem tissue. Conversely, the time when the lowest values for these elements are recorded (July and September) is the period when the proportion of leaf-to-stem is considered highest. We believe, therefore, that this apparent decrease in the concentration of this group of elements is a dilution reponse to the far greater concentrations of the major elements.

Also characteristic of this group are the generally higher element concentrations in old tissue than young tissue. Miroshnichenko (1976) found the same to be true for concentrations of $\mathrm{Al}$ and $\mathrm{Fe}$ in old versus young material of $A$. pauciflora from Kazakhstan. Except for As, Sb, and U, significant differences were found between the element concentrations of the tissue types (Table 1).

The reason for the reciprocal patterns in Groups 1 and 2 is not clear; however, it may simply represent a closure effect. The higher concentration of the major elements in young tissue (Group 1) proportionately excludes the content of the minor and trace elements.

The concentration of the Group 2 elements in the old tissue followed closely the general pattern observed for the young tissue. The lowest concentrations of elements within the old tissue were recorded in September. A similar dip occurred in the Group 1 element patterns. This may be due to a decrease in the ash yicld of the old tissue in September.

\section{Group 3}

Except for less within-tissue variability betwcen seasonal means, this group of 8 elements differs little from those of Group 2. The fact that no more than 2 means were distinguishable in this group (using Duncan's test) may be due, in part, to the high proportion of analytical error (Table 1) at the lowest analysis-of-variance level for $\mathrm{B}, \mathrm{F}, \mathrm{Mn}$, and $\mathrm{Zr}$. Similar to Group 2, the low seasonal values were recorded in July or September or both. Several of the Group 3 elements ( $\mathrm{B}, \mathrm{Mn}$, and $\mathrm{Mo}$ ) had higher element concentrations in young tissue than old, whereas $\mathrm{V}$ and $\mathrm{Zr}$ had higher concentrations in old tissue than young. No significant differences in the means of the 2 tissue types were noted for $\mathrm{Co}, \mathrm{F}$, or $\mathrm{Hg}$.

\section{Group 4}

These elements- $\mathrm{Li}, \mathrm{Sr}$, and $\mathrm{Se}$-were arbitrarily grouped together because they do not conform to the characteristics of the other 3 groups and also because the trends are not readily interpretable. The trends for $\mathrm{Li}$ and $\mathrm{Sr}$ are somewhat similar, showing a gradual increase in their concentrations in young tissue from July to January. The young tissue Se trend, however, is not similar to the trends in any other element. As with Group 1, reciprocal Se trends between young and old tissue from September to January may reflect return-flow.

\section{Conclusions}

Beetle (1960 p. 16) considered all of the late blooming types of Artemisia (i.e., the $A$. tridentatae section) remarkably stable in their chemical composition from season to season, a conclusion that was based on the compilation by Hamilton (1958). The results of our study of Wyoming big sagebrush, however, indicate strong seasonal variability for the majority of the elements analyzed. This seasonal variability for young sagebrush tissue appears to be associated, in part, with the seasonal fluctuations in ash yield, which itself is governed by overall sagebrush phenology and the proportion of high ash-yielding leaf material to low ash-yielding stem material. In general the element composition of young sagebrush tissue (predominantly leaves, stems, and inflorescences) fluctuates more, has higher concentrations, and shows greater differences between seasonal means than older sagebrush tissue (predominantly stems).

\section{Literature Cited}

Beetle, A.A. 1960. A study of sagebrush, the section Tridentatae of Artemisia. Univ. of Wyoming Agr. Exp. Sta. Bull. 368. Laramie. 83 p.

Beetle, A.A., and A. Young. 1965. A third subspecies in the Artemisia tridentata complex. Rhodora 67: 405-406.

Connor, J.J., J.R. Keith, and B.M. Anderson. 1976. Trace-metal variation in soils and sagebrush in the Powder River Basin, Wyoming and Montana. U.S. Geol. Survey J. Res. 4: 49-59.

DePuit, E.J., and M.M. Caldwell. 1973. Seasonal pattern of net photosynthesis of Artemisia tridentata. Amer. J. Bot. 60: 426-435.

Duncan, D.B. 1955. Multiple range and multiple $F$ tests. Biometrics 11: $1-42$.

Dunnewald, T.J. 1957. Wyoming soils and soil materials. Univ. of Wyoming Agr. Exp. Sta. Bull. 349. Laramie. 24 p.

Fernandez, O.A., and M.M. Caldwell. 1975. Phenology and dynamics of root growth of three cool semi-desert shrubs under field conditions. J. Ecol. 63: 703-714.

Grigal, D.F., L.F. Ohmann, and R.B. Brander. 1976. Seasonal dynamics of tall shrubs in northeastern Minnesota: biomass and nutrient element changes. Forest Sci. 22: 195-208.

Hamilton, J.W. 1958. Chemical composition of certain native forage plants. Univ. of Wyoming Agr. Exp. Sta. Bull. 356. Laramie. 44 p.

Harms, T.F. 1976. Analysis of plants and plant ashes by methods other than emission spectroscopy. p. 17-18. In: A. T. Miesch. Geochemical survey of Missouri-methods of sampling, laboratory analysis, and statistical reduction of data. U.S. Geol. Survey Prof. Pap 954-A.

Harner, R.F., and K.T. Harper. 1973. Mineral composition of grassland species of the eastern Great Basin in relation to stand productivity. Can. J. Bot. 51: 2037-2046.

Mack, R.N. 1977. Mineral return via the litter of Artemisia tridentata. Amer. Midl.Natur. 97: 189-197.

Mayland, H.F., and R.B. Murray. 1979. Mineral-cycling aspects within the sagebrush ecosystem. p. 62-73. In: Sagebrush Ecosystem Symposium Proc., April 27-28, 1978, Logan, UT.

Miesch, A.T. 1976. Geochemical survey of Missouri-methods of sampling, laboratory analysis, and statistical reduction of data. U.S. Geol. Survey Prof. Pap. 954-A. 39 p.

Miroshnichenko, N.V. 1976. Ash composition of dominating species. p. 196-198. In: Lavrenko, E.M., and I.V. Borissova (eds.). Biocomplex investigation in Kazakhstan, Part 3. USSR Academy of Sciences. Komarov Botanical Institute (in Russian).

National Res. Council, U.S., and Dep. Agr., Canada. 1969. United States-Canadian tables of feed composition. Nat. Acad. Sci. Pub. 1684. Washington, D.C.

Rodin, L.E., N.I. Bazilevich, and Yu. M. Miroshnichenko. 1972. Productivity and biogeochemistry of Artemisieta in the Mediterranean area. p. 193-198. In: USSR Academy of Sciences. Eco-physiological foundation of ecosystems productivity in arid zone. Proc. Int. Biol. Programme Symposium. Nauka Publ. House, Leningrad.

Shacklette, H.T. 1965. Element content of bryophytes. U.S. Geol. Survey Bull. 1198-D. $21 \mathrm{p}$.

Wallace, A., E.M. Romney, and V.Q. Hale. 1973. Sodium relations in desert plants: 1. Cation contents of some plant species from the Mojave and Great Basin Deserts. Soil Sci. 115:284-287.

West, N.E., R.J. Tausch, K.H. Rea, and P.T. Tueller. 1978. Taxonomic determination, distribution, and ecological indicator values of sagebrush within the pinyon-juniper woodlands of the Great Basin. J. Range Manage. 31: 87-92. 